\title{
Personal Factors and Faculty Job Satisfaction in Vietnam National University - Ho Chi Minh City
}

\author{
Minh-Quang Duong (Corresponding author) \\ University of Social Sciences and Humanities of Ho Chi Minh City, \\ 10-12 Dinh Tien Hoang Road, District 1, Ho Chi Minh City, Vietnam \\ E-mail: mqduong.ussh@yahoo.com
}

Received: August 6, 2014 Accepted: September 3, 2014 Published: September 16, 2014

doi:10.5296/ire.v2i2.6074 URL: http://dx.doi.org/10.5296/ire.v2i2.6074

\begin{abstract}
Faculty job satisfaction and teaching quality in higher education are closely related. Little is known about higher education faculty job satisfaction in developing countries like Vietnam. The purpose of this study is to investigate personal factors affecting faculty job satisfaction in Vietnamese higher education. The study used a questionnaire to survey 200 faculty members and an e-mail interview with 10 out of 200 those working full-time in the five member universities of Vietnam National University - Ho Chi Minh City. The finding of this study found that faculty members were moderately satisfied with their job. It also found that gender, educational attainment, and country of graduation were significant differences in faculty job satisfaction. This study showed that male faculty members were more satisfied than their female counterparts. Faculty members holding master's degree were more satisfied than those holding bachelor's degrees. Faculty members who received the highest degrees in Western countries were more satisfied than their colleagues who received the highest degrees in Asian countries or Vietnam.
\end{abstract}

Keywords: Job satisfaction, personal factor, Vietnamese higher education, faculty member

\section{Introduction}

One of the important components in higher education system are faculty members who are teaching and doing research at the educational institution and are playing important roles in improving teaching and knowledge, helping students learn how to apply the most effective way to achieve their educational objectives. Vietnam's Law of Education states that the goal of Vietnamese higher education is to educate learners in acquiring political and moral qualities, endeavor to serve the people, professional knowledge and practical skills relevant to 
the educational levels, and physical health, meeting the needs of construction and defense of the Fatherland (NASRV, 2005). Moreover, the goals of higher education are to provide in-depth knowledge, seek academic development, educate students, and coordinate national development demands (Johnes \& Taylor, 1990). These goals cannot be accomplished efficiently if faculty members are not satisfied with their profession; they will therefore not be able to increase their performance and will not contribute to education at higher institutions.

Employee attitude is very important for management to determine the behavior of workers in the organization. If employees are satisfied then it will create a pleasant atmosphere within the organization to perform in a better and efficient manner. Therefore, job satisfaction has become a major topic and a continuing topic for research studies. Several studies have found that employees who are satisfied with their jobs are more productive, creative and are more likely to be retained by the organization (Eskildsen \& Dahlgaard, 2000; Tang, Kim, \& Tang, 2000). Ali and Akhter (2009) found that a person with a high level of job satisfaction has a positive attitude towards the job, while a person who is dissatisfied with the job has a negative attitude. Dissatisfied employees are more likely to quit their jobs or be absent than satisfied employees (Hellriegel, Slocum, \& Woodman, 2001; Kohler \& Mathieu, 1993). Gruneberg (1979) showed that most individuals spend a large part of their lives at work. Therefore a detailed understanding of job satisfaction is the key to improving the well-being of a large number of working individual. The ways in which faculty members perceive the quality of their work life have a significant impact on their satisfaction or morale (Johnsrud \& Rosser, 2002).

Faculty satisfaction and dissatisfaction will affect the quality of an education system. Syed et al. (2012) recognize that faculty satisfaction is the most significant aspect in higher education and is important for the improvement and effectiveness of the higher education system. Yet, university faculty teaching is one of the most stressful occupations, requiring in-depth knowledge, and with pressure to teach and research, and to continually improve educational attainment and experience. Wood (1976) also observes that the quality of faculty of an educational institution depends on the job satisfaction of its employees. To achieve quality education and cultivate creative academic staff, job satisfaction among academic staff is a key; its various dimensions should be studied because satisfaction contributes highly in productivity and performance of individuals to the organization (Macerinskiene \& Vaiksnoraite, 2006).

Very few studies have been conducted in the area of job satisfaction in Vietnamese higher education sector. Garrett (1999) also believes that here is a need for more data to be gathered from developing countries, and for the theories to be tested in different cultural contexts and different professional, social and economic environments. This study intends to fill this gap. Through this study, it will identify and discuss factors in Vietnamese university academic's job which contribute most to their satisfaction as well as contribute to fill the gap in the literature regarding Vietnam and other developing countries. The study is designed to answer two questions: 1) What is the general level of faculty job satisfaction in Vietnamese 
universities? 2) Do any significant differences exist in the level of faculty job satisfaction regarding personal factors?

\section{Literature Review}

\subsection{Definition of Job Satisfaction}

There is no universal definition of the concept (Aziri, 2011; Evans, 1997), most of the definitions that exist in literature have a common theme. Different authors have different approaches towards defining job satisfaction. In Luddy (2005), job satisfaction is as the emotional reactions and feelings towards different aspects at work of the staff, which emphasized the causes of job satisfaction including job title, level of supervision, relationships with colleagues, job content, the structure of the organization, and so on.

The most common definition of job satisfaction in organizational research is from Locke (1976), who described job satisfaction as a pleasurable or positive emotional state resulting from the appraisal of one's job or job experiences. Job satisfaction is an attitude developed by an individual towards his or her job and job conditions. Thus, it is an emotional response to various dimensions of the job (Rastgar et al., 2012). Job satisfaction is concerned with the position emotions of employees towards the various aspects of the work and to what extend the results obtained meet their expectations from their job position.

\subsection{Measurement of Job Satisfaction}

There are many instruments available for measuring facets of job satisfaction. The Job Descriptive Index (JDI) was developed by Smith et al. (1969) which refers to five job aspects: type of work, the pay, the opportunities for promotion, the supervision, and the co-workers on the job. The INDSALES of Churchill et al. (1974) assesses satisfaction with customer, promotion, pay, company policy work, supervisor and co-workers. The Minnesota Satisfaction Questionnaire (MSQ) by Weiss et al. (1966), and the Job Satisfaction Survey (JSS) by Spector (1985) are theoretically suitable for most jobs. Weiss found that the MSQ consists of twenty dimensions of the job measuring satisfaction: ability utilization, achievement, activity, advancement, authority, company policies and practices, compensation, co-workers, creativity, independence, moral values, recognition, responsibility, security, social service, social status, supervision-human relations, supervision-technical, variety, and working conditions. On the other hand, Spector found that the JSS based on nine subscale facets: pay, promotion, supervision, benefits, rewards, operating conditions, co-workers, work itself, and communication.

Other studies of higher education have used different factors to measure job satisfaction. For example, Oshagbemi (1997) employed eight dimensions to measure satisfaction with respect to different components of university teachers' overall job satisfaction in the United Kingdom: teaching, research, administration and management, present pay, promotions, supervisor behavior; behavior of co-workers and working conditions. Kusku (2003) measured faculty job satisfaction in Turkey using the seven determinants: general satisfaction, management satisfaction, colleagues, other working group satisfaction, job satisfaction, work environment and salary satisfaction. Ssesanga and Garrett (2005) measured university faculty job 
satisfaction in Uganda using nine general factors: teaching, research, governance, remuneration, opportunities for promotion, supervision, co-worker's behavior, working environment and overall conditions. Chen et al. (2006) measured faculty job satisfaction in a private university in China using six factors: organization vision, respect, result feedback and motivation, management system, pay and benefits and work environment.

\subsection{Job Satisfaction and Personal Factors}

Personal factors also effect the faculty job satisfaction same as other professions. The literature provides evidence for a strong relationship between job satisfaction and personal factors namely gender (Bozeman \& Gaughan, 2011; Ghafoor, 2012), age (Abdul, 2013; Wong \& Heng, 2009), education level (Ghafoor, 2012), marital status (Bozeman \& Gaughan, 2011; Wong \& Heng, 2009), job position (Ghafoor, 2012; Wong \& Heng, 2009), total years teaching (Abdul, 2013), academic discipline (Springfield-Scott, 2000), children living in the home (Aisenberg \& Harrington, 1988; Bryson, Bryson, \& Johnson, 1978), work-family conflict (Calvo-Salguero et al., 2010; Lapierre et al., 2008), and so on. This study will use the personal factors such as gender, age, marital status, educational attainment, length of employment, academic rank, discipline, and country of graduation to view faculty job satisfaction.

\section{Methodology}

\subsection{Dependent and Independent Variables}

A dependent variable is a criterion or variable that is to be predicted or explain (Zikmund, 2003). Faculty job satisfaction is the dependent variable in this study. It consists of five dimensions namely salaries, bonus and welfare, faculty promotion, in-service teaching training, and in-service research training. Faculty members rated their level of satisfaction on a four-point Likert scale ranging from 1 = "very dissatisfied" to 4 = "very satisfied".

An independent variable is a variable that is expected to influence the dependent variable (Zikmund, 2003). In the study, personal factors are the independent variables. It includes gender, age, marital status, educational attainment, length of employment, country of graduation, and discipline. The purpose of selecting these factors in this study is to identify specific groups who have low level of job satisfaction in order to provide consultation and service that can enhance faculty job satisfaction in Vietnamese higher education.

\subsection{Sample}

The survey instrument was distributed to 230 faculty members at the five member universities of Vietnam National University - Ho Chi Minh City (VNU-HCM) namely the University of Technology, the University of Social Sciences and Humanities, the University of Science, the University of Information Technology, and the University of Economics and Law, of which 200 were returned, for an $87 \%$ return rate, which exceeds the $30 \%$ response rate most researchers require for analysis (Dillman, 2000; Malaney, 2002). In addition, 200 faculty members in VNU-HCM completed the survey instrument. The 10 of these were chosen for open-ended questions which were done using e-mail interviews. 


\subsection{Data Collection Procedure}

A questionnaire survey was sent to the representative faculty at each university who was further distributed questionnaires to faculty members in their department and school. Before distributing the questionnaire, a guideline was introduced to the faculty members in VNU-HCM, explaining the following points: 1) the purpose of the study, 2) a request for faculty not to write their name on the questionnaire, 3) assurance that questionnaires would not be handled or reviewed by any other person, 4) further assurance that the completed questionnaire would be analyzed for research purpose only and all personal information remains confidential. There was no time limit for faculty to answer the questionnaire so the faculty could answer at their own speed. After two weeks, we would be returned the all questionnaires of faculty members at each university.

The open-ended questions were sent to the participants. After receiving the questions, the participants responded by writing about their experiences and forwarded these to the questions. Each faculty member took twenty to thirty minutes to answer these questions, and immediately returned it to the writer by e-mail.

This study employs statistical methods of descriptive analyses, independent $t$-test and the analysis of variance (ANOVA) to analyze the data. Descriptive analysis is conducted to understand the general level of job satisfaction of faculty members in VNU-HCM. The independent $t$-test and ANOVA are used to examine the relationship between demographic factors and each dimension of faculty job satisfaction

\section{Results and Discussion}

\subsection{The General Level of Faculty Job Satisfaction in VNU-HCM}

The survey used a four-point Likert scale with responses ranging from $1=$ very dissatisfied to $4=$ very satisfied. In terms of Table 1 the findings indicated that faculty members in VNU-HCM were moderately satisfied with their jobs $(M=2.73, S D=0.73)$.

Table 1. The Results of Means (M) and Standard Deviations (SD) of Faculty Job Satisfaction Level in VNU-HCM

\begin{tabular}{lccc}
\hline \multicolumn{1}{c}{ Faculty Job Satisfaction Dimensions } & Scores range & $M$ & $S D$ \\
\hline Average of five dimensions & & 2.73 & 0.73 \\
1. Salaries & & 2.16 & 0.76 \\
2. Bonus and welfare & $1-4$ & 2.51 & 1.08 \\
3. Faculty promotion & & 3.25 & 1.11 \\
4. In-service teaching training & & 2.86 & 0.93 \\
5. In-service research training & & 2.84 & 0.81 \\
\hline
\end{tabular}

In this study, the results of descriptive analysis showed that the average of the five dimensions of job satisfaction is $68 \%(=2.73 / 4)$ indicating a moderate level of job satisfaction for faculty members in VNU-HCM by comparing the scale of 4 . This finding for 
Vietnam is supported by studies in Malaysia (Noordin \& Jusoff, 2009), India (Gautam et al., 2006), Jamaica (Brown \& Sargeant, 2007), and around the world (Bentley et al., 2013). These studies used a five-point Likert scale with responses ranging from $1=$ very dissatisfied to $5=$ very satisfied to measure the level of faculty job satisfaction. These studies showed that the average level of job satisfaction for faculty members in Malaysia was $76 \%(=3.82 / 5)$, in Jamaica, it was $67 \%(=3.38 / 5)$, and in Indian, it was 61.2 (medium $=51$ to 70 ). Bently et al. (2013) examined faculty job satisfaction across countries and found that the average level of faculty job satisfaction in the United State (U.S.) was 73\% (=3.69/5), in Australia 68\% (= $3.42 / 5)$, in Japan 72\% (=3.62/5), in South Africa 67\% (=3.37/5), in Portugal 67\% (=3.39/5) and in the United Kingdom $66 \%(=3.34 / 5)$.

Although each study used different methods, approaches and instruments to measure job satisfaction for faculty members in higher education, this study, like the other cited above, indicated that Vietnamese faculty members were moderately satisfied with their jobs. This means that the level of faculty satisfaction in Vietnam is comparable to those in both developing and developed countries. However, there is still much room for university administrators to improve the level of job satisfaction of faculty members in VNU-HCM.

\subsection{The Significant Different between Personal Factors and Faculty Job Satisfaction in VNU-HCM}

This study used a combination of personal factors such as gender, age, marital status, educational attainment, length of employment, country of graduation, and discipline which were identified as key factors to determine faculty job satisfaction in VNU-HCM. The findings of this study show that there were significant differences regarding faculty job satisfaction and personal factors. Three of the seven dimensions of personal factors including gender, educational attainment, and country of graduation were significant differences on faculty job satisfaction in VNU-HCM.

Regarding the relationship in job satisfaction between male and female faculty in VNU-HCM, Table 2 shows that there were significant differences between the level of job satisfaction of male and female faculty members $(t=-2.719, p<0.01)$. The finding of post-hoc comparison shows that male faculty members $(M=2.81, S D=0.73)$ were more satisfied with their jobs than their female colleagues $(M=2.50, S D=0.67)$.

In terms of educational attainment, Table 2 shows that there were significant differences in faculty job satisfaction between participants with different degrees $(F=3.445, p=<0.05)$. Furthermore, the finding post-hoc comparison shows that faculty members holding master's degrees $(M=2.93, S D=0.91)$ were more satisfied with their jobs than those holding bachelor's degrees $(M=2.64, S D=0.61)$. It shows no significant differences in job satisfaction between faculty members holding doctoral and both those holding masters and bachelor's degrees.

Regarding the relationship between faculty job satisfaction in VNU-HCM and country of graduation, Table 2 shows that there was significant differences regarding faculty job satisfaction and country where highest degrees received $(t=5.756, p<0.01)$. The finding of 
post-hoc comparison shows that faculty members who received their highest degrees in Western countries $(M=3.03, S D=0.86)$ were more satisfied with their jobs than colleagues who received their highest degrees in Asian countries $(M=2.60, S D=0.72)$ and Vietnam $(M$ $=2.64, S D=0.64)$. It shows no significant differences in job satisfaction between faculty members who received their highest degrees in Asian countries and Vietnam.

Table 2. The Results of ANOVA and $t$-test of Personal Factors on Faculty Job Satisfaction in VNU-HCM

\begin{tabular}{|c|c|c|c|c|}
\hline Personal factors & $M$ & $S D$ & $\begin{array}{c}t \text {-test/ } \\
\text { ANOVA }\end{array}$ & Post-hoc comparisons \\
\hline \multicolumn{5}{|l|}{ Gender } \\
\hline Female & 2.50 & 0.67 & \multirow{2}{*}{$-2.719 * *$} & \\
\hline Male & 2.81 & 0.73 & & \\
\hline \multicolumn{5}{|l|}{ Age (average age $=33.99)$} \\
\hline Under 30 & 2.79 & 0.71 & \multirow{3}{*}{0.634} & \\
\hline $30-40$ & 2.73 & 0.78 & & \\
\hline Over 40 & 2.58 & 0.44 & & \\
\hline \multicolumn{5}{|l|}{ Marital status } \\
\hline Single & 2.72 & 0.72 & \multirow{2}{*}{-0.066} & \\
\hline Married & 2.73 & 0.74 & & \\
\hline \multicolumn{5}{|l|}{ Educational attainment } \\
\hline Bachelor's degree (B.A) & 2.64 & 0.61 & \multirow{3}{*}{$3.445^{*}$} & \multirow{3}{*}{ (B.A) $<$ (M.A) } \\
\hline Master's degree (M.A) & 2.93 & 0.91 & & \\
\hline Doctoral degree (Dr.) & 2.67 & 0.71 & & \\
\hline \multicolumn{5}{|l|}{ Length of employment (years) } \\
\hline Less than 1 & 2.64 & 0.63 & \multirow{5}{*}{1.100} & \\
\hline $1-5$ & 2.86 & 0.81 & & \\
\hline $6-10$ & 2.79 & 0.82 & & \\
\hline $11-15$ & 2.59 & 0.63 & & \\
\hline 16 or more & 2.60 & 0.41 & & \\
\hline \multicolumn{5}{|l|}{ Country of graduation } \\
\hline Vietnam & 2.64 & 0.64 & \multirow{3}{*}{$5.756^{* *}$} & \multirow{3}{*}{$\begin{array}{c}\text { (Vietnam), (Asian) }< \\
\text { (Western) }\end{array}$} \\
\hline Asian countries & 2.60 & 0.72 & & \\
\hline Western countries & 3.03 & 0.86 & & \\
\hline \multicolumn{5}{|l|}{ Discipline } \\
\hline Technology & 2.82 & 0.67 & \multirow{3}{*}{2.498} & \\
\hline Social Science and Humanities & 2.78 & 0.74 & & \\
\hline Nature Sciences & 2.56 & 0.78 & & \\
\hline
\end{tabular}

Note. ${ }^{*} p<.05 * * p<.01$. 
Faculty members in VNU-HCM belongs to different age groups, the average age of participants was approximately thirty-four years $(M=33.99)$. Table 2 shows that there was no significant differences in faculty job satisfaction among different age groups $(F=0.634, p>$ 0.05). In terms of marital status, there was no significant differences in faculty job satisfaction between married and single participants $(t=-0.066, p>0.05)$. For length of employment at current position, Table 2 also shows that there was no significant differences regarding faculty job satisfaction in VNU-HCM and length of employment $(F=1.100, p>$ $0.05)$. Finally, this study also examines the relationships regarding faculty job satisfaction in VNU-HCM and discipline. Table 2 shows that there was no significant difference regarding the level of faculty satisfaction and discipline $(F=2.498, p>0.05)$.

In this study, the findings of independent $t$-test and one-way ANOVA found that there were significant differences regarding job satisfaction and personal factors of the respondents. This finding had similar by studies in Singapore (Paul \& Phua, 2011), Pakistan (Ghafoor, 2012; Mehboob et al., 2012), South Africa (Schulze, 2006), the U.S. (Castillo \& Cano, 2004; Seifert \& Umbach, 2008), and Uganda (Ssesanga \& Garrett, 2005).

A statistically significant difference has found between the level of satisfaction of male and female in their job. Male faculty members in VNU-HCM were generally more satisfied with their jobs than their female counterparts. This finding for Vietnam was consistent with studies at the U.S., including Castillo and Cano (2004), Nyquist, Hitchcock, and Teherani (2000), and Springfield-Scott (2000). According to Castillo and Cano (2004), male faculty members in the U.S. $(M=4.06, S D=0.50)$ were more satisfied than female counterparts $(M=3.78, S D$ $=0.57$ ). Springfield-Scott (2000) found that this may be due to overshadowing, traditional, male dominance in the U.S. in establishing and implementing major policies, administrative directives and long-range planning. Like these studies in the U.S., this study found that in Vietnam, male had more satisfied than their female colleagues because males might be higher job mobility, more supported to focus on job, and held leadership positions in organizations. This means that factors such as family roles and culture affected faculty job satisfaction in VNU-HCM. A faculty member said,

I think the result is quite true. Because female faculty member often spend more time taking care of the whole family, their activities rellated to teaching were not as focused as their male counterparts. Moreover, male faculty members often hold leadership positions in their organizations and have more power to make decisions on the job compared to their female peers.

The findings of this study showed that there were significant differences regarding faculty job satisfaction in VNU-HCM and educational attainment. There are identified many results from different studies in regards to faculty job satisfaction and educational attainment. Studies of faculty job satisfaction in North Cyprus by Eyupoglu and Saner (2009) and in the U.S. by Schroder (2008) found that faculty holding doctoral degrees displayed significantly higher levels of job satisfaction than their counterparts with masters or bachelor's degrees. In a study of faculty members in Singapore, Paul and Phua (2011) found that the satisfaction 
levels of faculty holding bachelor's degrees were marginally higher than those holding masters or doctoral degrees. In Vietnam, this study found that faculty holding master's degrees were more satisfied in their jobs than those holding bachelor's degrees. Blanchflower and Oswald (1994) showed that educational attainment contributes to a higher level of income, faster promotion, and finding better jobs.

Reasons why faculty members holding master's degrees were more satisfied with their jobs than those holding bachelor's degrees consist of qualified to meet teaching standards, qualified to participate in the specialist knowledge at work such as academic reviewer, scientific council, qualified to participate in teaching at different institutions, and qualified to find opportunities for promotion and salary increase. As one faculty member explained,

In my opinion, when teaching at the undergraduate level, faculty members should have a higher qualification than a bachelor's degree in order to impart knowledge to students. Moreover, when faculty members have a master's degree, they have more opportunities for career advancement and professional development.

Faculty job satisfaction generally increases with highest educational attainment (Gardner \& Oswal, 2002; Metle, 2001). In Vietnam, however, faculty members with a master's degree can meet the minimum requirements and standards to teach at a university; but, there is still a wide the gap between faculty holding master's degrees and faculty holding bachelor's degrees in terms of welfare, benefits, rights and chances. This gap is not significant in faculty members with master's degrees and doctoral degrees.

Finally, the findings of this study show a significant differences regarding faculty job satisfaction in VNU-HCM and country of graduation. This finding for Vietnam contrasts with the situation in Malaysia; Noordin and Jusoff (2009) found no significant differences between Asian and Western educated respondents with regard to faculty job satisfaction. In Vietnam, however, Western-country-degree holders were more satisfied with their jobs than Vietnam and Asian educated respondents. Based on factors such as qualification, knowledge and confidence, Vietnamese universities prefer job applicants with Western degrees than Asian and Vietnam degrees. One faculty member elaborated,

The training system in Western countries not only provided good technical knowledge, but it also improved self-confidence for learners from different environments. This confidence helped make them more satisfied in Vietnamese universities.

\section{Conclusion}

A person with a high level of job satisfaction has a positive attitude towards the job, while a person who is dissatisfied with the job has a negative attitude. Therefore a detailed understanding of job satisfaction is the key to improving the well-being of a large number of working individual. Job satisfaction contributes to efficient services and high performance, and will increase organizational productivity. Faculty job satisfaction is their positive feelings 
with the educational process and its results, their enthusiasm in the process of work, and their relations with students, colleagues and administration.

The findings of this study showed that faculty members were female faculty, faculty holding bachelor's degree, and faculty who received their highest degree in Asian countries and Vietnam had low satisfaction in their jobs. Policy makers and university administrators in VNU-HCM should focus on improving satisfaction levels for female faculty, faculty holding bachelor's degree, and faculty who received their highest degree in Asian countries and Vietnam.

It is hoped that the barrier to the job satisfaction of faculty members in VNU-HCM found in this study may be help administrator to develop a work environment and culture that would allow higher levels of faculty job satisfaction and contribute to improvement in the quality of faculty members in Vietnamese higher education. Furthermore, the findings of this study can also contribute to filling the gap in the literature regarding Vietnam and other developing countries.

\section{References}

Abdul, Q. C. (2013). Job satisfaction of university teachers across the demographic. Bulletin of Education and Research, 35(1), 1-15.

Aisenberg, N., \& Harrington, M. (1988). Women of academe: Outsiders in the sacred grove. Amherst, MA: University of Massachusetts Press.

Ali, T., \& Akhter, I. (2009). Job satisfaction of faculty members in private universities - in context of Bangladesh. International Business Research, 2(4), 167-175. http://dx.doi.org/10.5539/ibr.v2n4p167

Aziri, B. (2011). Job satisfaction: A literature review. Management Research and Practice, 3(4), 77-86.

Bentley, P. T., Coates, H., Dobson, I. R., Goedegebuure, L., \& Meek, V. L. (2013). Job satisfaction around the academic world. The changing academic - The changing academic profession in international comparative perspective 7. Netherlands: Springer. http://dx.doi.org/10.1007/978-94-007-5434-8

Blanchflower, D. G., \& Oswald, A. J. (1994). Estimating a wage curve for Britain. Economic Journal, 104(426), 1025-1043. http://dx.doi.org/10.2307/2235062

Bozeman, B., \& Gaughan, M. (2011). Job satisfaction among university faculty: Individual, work, and institutional determinants. Journal of Higher Education, 82(2), 154-186. http://dx.doi.org/10.1353/jhe.2011.0011

Brown, D., \& Sargeant, M. A. (2007). Job satisfaction, organizational commitment, and religious commitment of full-time university employees. Journal of Research on Christian Education, 16, 211-241. http://dx.doi.org/10.1080/10656210701647613 


\section{Macrothink}

International Research in Education

ISSN 2327-5499

2014, Vol. 2, No. 2

Bryson, R., Bryson, J. B., \& Johnson, M. F. (1978). Family size, satisfaction, and productivity in dual-career couples. Psychology of Women Quarterly, 3(1), 67-77. http://dx.doi.org/10.1111/j.1471-6402.1978.tb00526.x

Calvo-Salguero, A., Carrasco-Gonzalez, A. M., Salinas-Martinez de Lecea, J. M. (2010). Relationship between work-family conflict and job satisfaction: The moderating effect of gender and the salience of family and work roles. African American Journal of Business Management, 4(7), 1247-1259.

Castillo, J. X., \& Cano, J. (2004). Factors explaining job satisfaction among faculty. Journal of Agriculture Education, 45(3), 65-74. http://dx.doi.org/10.5032/jae.2004.03065

Chen, S. H., Yang, C. C., Shiau, J. Y., \& Wang, H. H. (2006). The development of an employee satisfaction model for higher education. TQM Magazine, 1(5), 484-500. http://dx.doi.org/10.1108/09544780610685467

Churchill, G. A., Ford, N. M., \& Walker, O. C. (1974). Measuring the job satisfaction of industrial salesmen. Journal of Marketing Research, 11, 254-260. http://dx.doi.org/10.2307/3151140

Dillman, D. A. (2000). Mail and internet surveys: The tailored design method. New York: John Wiley and Son.

Eskildsen, J. K., \& Dahlgaard, J. J. (2000). A causal model for employee satisfaction. Total Quality Management, 11(8), 1081-1094. http://dx.doi.org/10.1080/095441200440340

Evans, L. (1997). Addressing problems of conceptualization and construct validity in researching teachers' job satisfaction. Educational Research, 39(3), 319-331. http://dx.doi.org/10.1080/0013188970390307

Eyupoglu, S. Z., \& Saner, T. (2009). Job satisfaction: Does rank make a difference? African Journal of Business management, 3(10), 609-615.

Gardner, J., \& Oswald, A. (2002). How does education affect mental well-being and job satisfaction? Paper presented at the Conference of National Institute of Economic and Social Research at the University of Birmingham, $\mathrm{UK}$.

Garrett, M. R. (1999). Teacher job satisfaction in developing countries. Educational research supplemental series, ERIC Document Reproduction Service No.ED 459150

Gautam, M., Mandal, K., \& Dalal, R. S. (2006). Job satisfaction of faculty members of veterinary sciences: an analysis. Livestock Research for Rural development, 18(6).

Ghafoor, M. M. (2012). Role of demographic characteristics on job satisfaction. Far East Journal of Psychology and Business, 6(1), 30-45.

Gruneberg, M. M. (1979). Understanding job satisfaction. London: The Macmillan Press Ltd. 
Hellriegel, D., Slocum, J. W., \& Woodman, R. W. (2001). Organizational behavior ( $9^{\text {th }}$ ed.). Thomson Learning: South-western College Publishing.

Johnes, J., \& Taylor, J. (1990). Performance Indicators in Higher Education. Buckingham: SRHE and Open University Press.

Johnsrud, L. K., \& Rosser, V. J. (2002). Faculty members' morale and their intention to leave: A multilevel explanation. Journal of Higher Education, 73(4), 518-542. http://dx.doi.org/10.1353/jhe.2002.0039

Kohler, S. S. \& Mathieu, J. E. (1993). An examination of the relationship between affective reactions, work perceptions, individual resource characteristics, and multiple absence criteria. Journal of Organizational Behavior, 14, 515-530. http://dx.doi.org/10.1002/job.4030140602

Kusku, F. (2003). Employee satisfaction in higher education: the case of academic and administrative staff in Turkey. Career Development International, 8(7), 347-356. http://dx.doi.org/10.1108/13620430310505304

Lapierre, L. M., Spector, P. M., Allen, T. A., Poelman, S., Cooper, C. L., O’Driscoll, M. P., Sanchez, J., Brough, P., \& Kinnunen, U. (2008). Family-supportive organization perceptions, multiple dimensions of work-family conflict and employee satisfaction: A test of model across five samples. Journal of Vocational Behavior, 73, 92-106. http://dx.doi.org/10.1016/j.jvb.2008.02.001

Locke, E. A. (1976). The nature and causes of job satisfaction. In M.D. Dunnette (Ed.), Handbook of industrial and organizational psychology (pp. 1297-1349). Chicago: Rand McNally.

Luddy, N. (2005). Job satisfaction amongst employees at a public health institution in the Western Cape. University of Western Cape, South McGraw Hill Irwin, Africa.

Macerinskiene, I., \& Vaiksnoraite, B. (2006). The role of higher education to economic development. Vadyba / Management, 2(11), 82-90

Malaney, G. D. (2002). You still need high response rates with web-based surveys. Student Affairs On-Line, 3(1). Retrieved from http://studentaffairs.com/ejournal/Winter_ 2002/rates.html

Mehboob, F., Sarwar, M. A., \& Bhutto, N. A. (2012). Factors affecting job satisfaction among faculty members. Asian Journal of Business and Management Sciemces, 1(12), 1-9.

Metle, M. K. (2001). Education, job satisfaction and gender in Kuwait. International Journal of Human Resource Management, 12(2), 311-332. http://dx.doi.org/10.1080/09585190122366

NASRV (National Assembly of the Socialist Republic of Vietnam). (2005). Education Law. Hanoi: Education Press.

Noordin, F., \& Jusoff, K. (2009). Levels of job satisfaction amongst Malaysian academic staff. Asian Social Science, 5(5), 122-128. http://dx.doi.org/10.5539/ass.v5n5p122 


\section{Macrothink}

International Research in Education

ISSN 2327-5499

2014, Vol. 2, No. 2

Nyquist, J. G., Hitchcock, M. A., \& Teherani, A. (2000). Faculty Satisfaction in Academic

Medicine. New Directions for Institutional Research, 2000(105), 33-43. http://dx.doi.org/10.1002/ir.10503

Oshagbemi, T. (1997). The influence of rank on the job satisfaction of organizational members. Journal Managerial Psychology, 12(8), 511-519. http://dx.doi.org/10.1108/02683949710189111

Paul, E. P., \& Phua, S. K. (2011). Lecturers' job satisfaction in a public tertiary institution in Singapore: ambivalent and non-ambivalent relationships between job satisfaction and demographic variables. Journal of Higher Education Policy and Management, 33(2), 141-151. http://dx.doi.org/10.1080/1360080X.2011.550087

Rastgar, A. A., Davoudi, S. M. M., Oraji, S., \& Fartash, K. (2012). Illustrate the important linkage between perception of justice and job satisfaction. Asian Jourmal of Research in Social Sciences and Humanities, 2(5), 270-288.

Schroder, R. (2008). Job satisfaction of employees at a Christian university. Journal of $\begin{array}{lllll}\text { Research on } \quad \text { Christian 225-246. } & \text { Education, }\end{array}$ http://dx.doi.org/10.1080/10656210802433467

Schulze, S. (2006). Factors influencing the job satisfaction of academics in higher education. South African Journal of Higher Education, 20(2), 318-335.

Seifert, T. A., \& Umbach, P. D. (2008). The effects of faculty demographic characteristics and disciplinary context on dimensions of job satisfaction. Research in Higher Education, 49(4), 357-381. http://dx.doi.org/10.1007/s11162-007-9084-1

Smith, P. C., Kendall, L. M., \& Hulin, C. L. (1969). The measurement of satisfaction in work and retirement. Chicago: Rand McNally.

Spector, P. E. (1985). Measurement of human service staff satisfaction: Development of the job satisfaction survey. American Journal of Community Psychology, 13, 693-713. http://dx.doi.org/10.1007/BF00929796

Springfield-Scott, M. (2000). Faculty job satisfaction in a university work environment. Thresholds in Education, 25-32.

Ssesanga, K., \& Garrett, R. M. (2005). Job satisfaction of university academics: Perspectives from Uganda. Higher Education, 50, 33-56. http://dx.doi.org/10.1007/s10734-004-6346-0

Syed, A. A. S. G., Bhatti, N., Michael. S., Shaikh, F. M., \& Shah, H. (2012). Job satisfaction of faculty members of university in Pakistan: A case study of university of Sindh-Jamshoro. Modern Applied Science, 6(7), 89-95.

Tang, T. L. P., Kim, J. W., \& Tang, D. S. H. (2000). Does attitude toward money moderate the relationship between intrinsic job satisfaction and voluntary turnover? Human Relations, 53(2), 213-245. 


\section{Macrothink}

International Research in Education

ISSN 2327-5499 2014, Vol. 2, No. 2

Weiss, D., Dawis, R., Lofquist, L., \& England, G. (1966). Instrumentation for the theory of work adjustment. University of Minnesota, Minneapolis.

Wood, O. R. (1976). A research project: Measuring job satisfaction of the community college staff. Community College Review, 3(3), 56-64. http://dx.doi.org/10.1177/009155217600300309

Wong, E. S. K., \& Heng, T. N. (2009). Case study of factors influencing job satisfaction in two Malaysian universities. International Business Research, 2(2), 86-98. http://dx.doi.org/10.5539/ibr.v2n2p86

Zikmund, G. W. (2003). Exploring marketing research (8th ed.). South-Western: Thomson.

\section{Copyright Disclaimer}

Copyright reserved by the authors.

This article is an open-access article distributed under the terms and conditions of the Creative Commons Attribution license (http://creativecommons.org/licenses/by/3.0/). 